E3S Web of Conferences 1, 20001 (2013)

DOI: $10.1051 / \mathrm{e} 3$ sconf $/ 20130120001$

(c) Owned by the authors, published by EDP Sciences, 2013

\title{
Street Dust: Source and Sink of Heavy Metals To Urban Environment
}

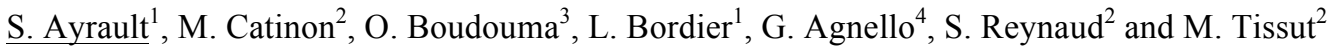 \\ ${ }^{1}$ Laboratoire des Sciences du Climat et de l'Environnement, UMR 8212, CEA-CNRS-UVSQ/IPSL, 91198 \\ Gif-sur-Yvette, FRANCE, sophie.ayrault@lsce.ipsl.fr \\ ${ }^{2}$ Laboratoire LECA, UMR 5553, Equipe Pollution, Environnement, Ecotoxicologie et Ecoremédiation, Univ. J. Fourier, \\ 38041 Grenoble, FRANCE, Mickael.Catinon@gmail.com \\ ${ }^{3}$ Service du MEB, UFR928, Université Pierre et Marie Curie, 75252 Paris VI, FRANCE, boudouma@ccr.jussieu.fr \\ ${ }^{4}$ Evinrude, Espace St Germain, 38200 Vienne, FRANCE, contact@evinrude.fr
}

\begin{abstract}
Air-transferred solid material accumulated for 40 years in different places in an urban area, Grenoble city, France. An appropriate fractionation procedure allowed to separate: 1) a coarse inorganic fraction, 2) a coarse organic fraction, 3) a slowly depositing organo-clay fraction and 4) very fine particles. The composition of each fraction was determined for 20 elements and for isotopic lead signature. The organo-clay fraction was especially rich in $\mathrm{Ag}, \mathrm{Cd}, \mathrm{Co}, \mathrm{Cr}, \mathrm{Ni}$ and $\mathrm{Ti}$. The sand fraction showed very high concentrations specifically in $\mathrm{Cu}, \mathrm{Pb}$ and $\mathrm{Fe}$. In contrast, $\mathrm{Cd}$ and $\mathrm{Zn}$ were mainly accumulated in the coarse organic fraction. The SEM-EDX study of the coarse inorganic fraction showed the presence of red particles associating $\mathrm{Pb}$ and $\mathrm{Fe}$, black particles rich in $\mathrm{Cu}$ and typical fly ashes originating mostly from iron industry. This sand fraction is suspected to contribute to the contamination of the organo-clay fraction through adsorption. The $\mathrm{Pb}-\mathrm{Fe}$ contamination likely originates from the neighbouring road surface contaminated by car traffic for several decades. The ${ }^{206} \mathrm{~Pb} /{ }^{207} \mathrm{~Pb}$ ratio showed that these street dust samples may contain up to $50 \%$ of lead originated from leaded gasoline additives, twelve years after their prohibition. All these features clearly differ from the composition found for the deposit on tree bark in the same place. These results demonstrate that the deposition over several decades is a very complex phenomenon which requires multi-techniques investigations to be understood thoroughly. They also show that large dense particles which can only be transported on a limited distance by high magnitude events may play a major role in the long-term contamination of urban soils.
\end{abstract}

Key words: Heavy metals, Air pollution; Pb isotopes; dense particles; SEM-EDX; ICP-MS.

\section{Introduction}

Atmospheric contamination by diverse components of natural or anthropogenic origins is a subject of great concern (e.g., Zereini et al., 2005), as is the case for water pollution (e.g., Mondal et al., 2010), and especially for particulate metals in urban environment (e.g., Harrison et al., 1997). For animals having a respiratory system adapted to terrestrial conditions, including humans, there is a toxicological danger in direct inhalation of atmospheric particulate matter (e.g., Costa and Dreher, 1997). However, a second type of danger may exist for different kinds of living beings, which depends on the uptake, through several ways, of a mixture of particles of atmospheric origin deposited on the earth surface. Such an exposure occurs mainly through transcutaneous transfer or digestive uptake (Laidlaw and Filippelli, 2008). The functional perturbations which may affect living organisms as well as ecosystems heavily depend on the rate of deposition of the atmospheric components. It is now well known that this rate greatly changes from one place to another, with a great part played by terrestrial relief and climatic factors (e.g., Kume et al., 2009). Consequently, severe biological disturbances may appear in places submitted to a high-rate deposition of atmospheric pollutants as it is the case in mining estates (Cirera et al., 2009) or in volcanic regions (Amaral et al., 2008). Thus, it is crucial to identify such contaminated places, try to suppress the emission of the involved pollutants and use remediation strategies (Kidd et al., 2009).

The measurement of atmospheric deposition on tree barks or lichens has been a useful tool used for years in the detection of these heavily-polluted places as these matrices are more satisfactory than soil (Bargagli, 1998). However, these matrices were difficult to use accurately 
for studying deposition over periods longer than one or two decades. It would be valuable to look for other matrices having the obvious ability of accumulating atmospheric deposits over a longer time. Results of several fruitful attempts were previously published in which new matrices such as bark pockets (Bellis et al., 2002), attic dust (Cizdziel and Hodge, 2000) or ceiling dusts (Davis and Gulson, 2005) were studied.

In this report, we sampled street dust in different places and structures of the Grenoble city, France. The atmospheric deposition on trees in this urban area was extensively studied between 2004 and 2010, allowing accurate comparisons (Catinon et al., 2008; 2009; 2011).

\section{Materials and Methods}

The experimental sites chosen for this study were: (1) a bike shed made of concrete and built on 1970 in the University Campus (University Joseph Fourier, Saint Martin d'Hères, Isère, France). This site stands $800 \mathrm{~m}$ away from the A41 highway Grenoble-Chambéry with a 50000 vehicles/day traffic and $4 \mathrm{~km}$ away from the center of the town (150 000 inhabitants) at an altitude of $200 \mathrm{~m}$, in the Isère River valley, surrounded by mountains reaching altitudes over $2000 \mathrm{~m}$. (2) a car park in a residential area built in 1970 and never cleaned for street dust and stands $1 \mathrm{~km}$ away from the site. (3) a street sewer inlet constituting a dust trap for an unknown duration in the city centre. After fractionation (Catinon et al., submitted), the organic matter content was determined using loss on ignition. The trace and major element content was determined by inductively coupled plasma - mass spectrometry (ICP-MS) after total digestion. Lead isotope ratios $\left({ }^{206} \mathrm{~Pb} /{ }^{207} \mathrm{~Pb}\right)$ were measured in the digestion solutions that were also used for elemental concentration determinations, after appropriate dilution, using a ICP-QMS (Ayrault et al., 2012). Sample characterisation was performed using Scanning Electron Microscope (SEM), allowing a spatial resolution down to $1.0 \mathrm{~nm}$, coupled to an Energy Dispersive X-ray (EDX) microanalysis system.

\section{Results and Discussion}

The particles trapped in the street dust samples were very heterogeneous for the size and density, as well as for their origins (biological, geogenic, anthropogenic). It obviously results from complex transfer processes: slow deposition of small particles during low-speed wind periods, wet deposition during rain or fog events, and transfer of heavy material during storms. Such trapping is probably not completely cumulative as high magnitude events might partly disperse the previously accumulated particles. However, the results obtained on this material proved a long-term accumulation of urban pollutants in these street dust samples. Due to their high heavy metal concentration shown by ICP-MS coupled to the presence of pure crystals of these metals as shown by SEM-EDX analysis, we concluded that the source of the dense particles seems obviously anthropogenic and located for one part at a limited distance from the studied place. The nature of some metallic particles, their shape and lack of polishing suggest that contamination may partly originate from car metallic components wear (Sternbeck et al., 2002). Three metallic contaminants $(\mathrm{Cu}, \mathrm{Fe}, \mathrm{Pb})$ reach their highest concentrations in the coarse inorganic, sandy, fraction. The large amounts of the same metals found in the organoclay fraction suggest that they are likely to result from a low distribution from sand to dispersed forms which would adsorb on clay or organic matter. However, the opposite exchange may be also considered which would be crystallization on sand grains from the adsorbed amount or directly from the atmospheric deposit, giving the structures associated to sand and seen in SEM-EDX analyses (Fig. 1). When considering the elements content of the dust and comparing it to the deposit on tree bark of the same age, several elements show that the street dusts are significantly enriched in $\mathrm{Pb}, \mathrm{Cd}, \mathrm{Cu}, \mathrm{Co}, \mathrm{Zn}$ and $\mathrm{As}$. When comparing the dust element content to the reference UCC (Taylor and Mc Lennan., 1985), the enrichment factor (EF) showed very high enrichment for $\mathrm{Pb}, \mathrm{Cu}, \mathrm{Cd}$ and $\mathrm{Zn}$ in the dust. The distribution of $\mathrm{Pb}, \mathrm{Cd}, \mathrm{Cu}, \mathrm{Co}, \mathrm{Zn}$ and As among the different fractions allows to range these elements, known as urban pollutants in two classes: (1) the elements such as $\mathrm{Cu}$ or $\mathrm{Pb}$ which accumulate mainly in the coarse inorganic fraction, and (2) the elements more uniformly distributed but showing their major accumulation in the coarse organic fraction $(\mathrm{Cd}, \mathrm{Zn}$, $\mathrm{Co}$, and As). This discrepancy is probably related to a difference of solubility of the different elements but is also likely to depend on their ability to crystallize on sand grains, which seems to be high for $\mathrm{Cu}, \mathrm{Pb}$ and $\mathrm{Fe}$, as shown by SEM-EDX pictures but low for $\mathrm{Zn}$ and $\mathrm{Cd}$. Another important factor may be their ability to concentrate inside organic matter. The major contaminating elements present in the dust confirm a high contribution of car traffic emission due for one part to leaded gasoline additives but, for another one, due to brake or tyre wear ( $\mathrm{Fe}, \mathrm{Zn}, \mathrm{Co})$ as reported by Thorpe and Harisson (2008). However, As and Co high ratios may have another origin. Furthermore, $\mathrm{Sb}$, which seems to be a common component of brake pads (Iijima et al., 2008), is not present in the accumulated dust at a noteworthy high level. The isotopic ${ }^{206} \mathrm{~Pb} /{ }^{207} \mathrm{~Pb}$ ratio and $\mathrm{Fe}, \mathrm{Zn}$ and $\mathrm{Co}$ concentrations found in the coarse inorganic fraction suggests that this heavy sand fraction was a main sink in which car exhaust and wear components could concentrate and remain for years, as previously shown by Sutherland et al. (2003). As shown by a sequential extraction test, the dust is a source of gasoline type lead to the environment through remobilisation by water. Some of the deposits associated to sand grains shown by SEM-EDX in our work may result from iron particles issued from car exhaust-pipes, on which dispersed, liquid $\mathrm{Pb}$ could adsorb and crystallize 


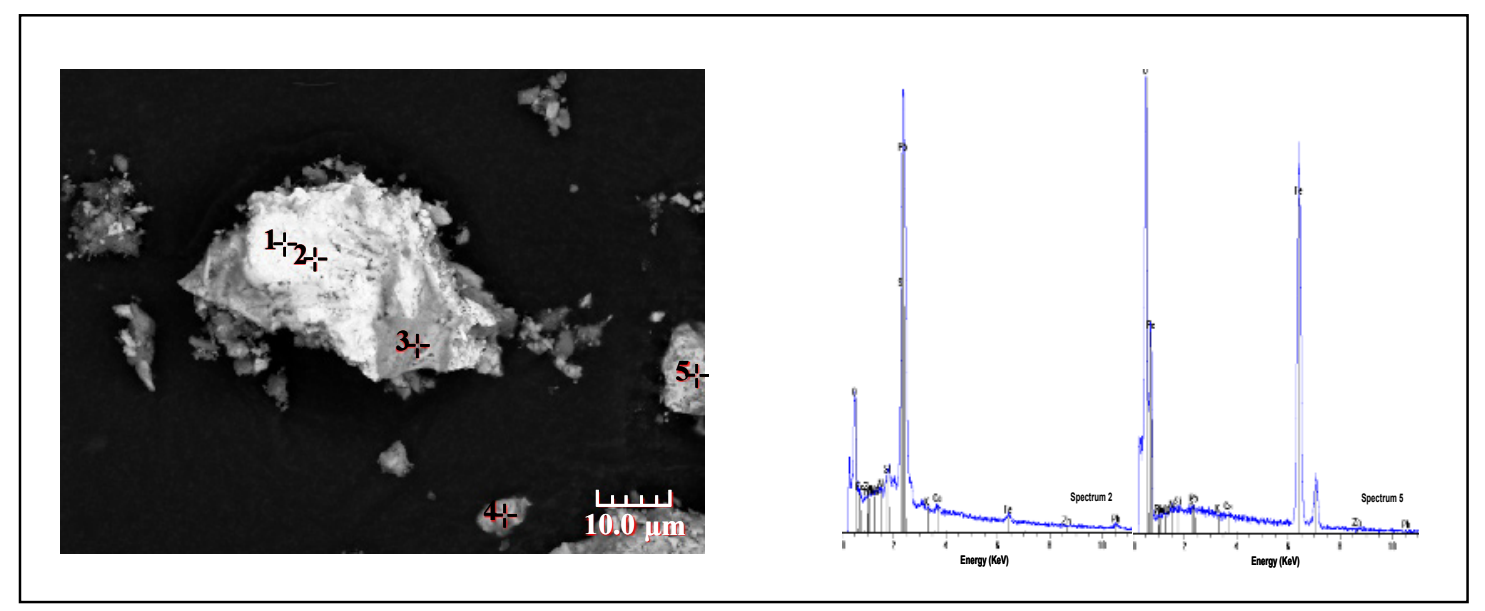

Fig. 1. SEM picture and EDX spectra showing the presence of $\mathrm{Pb}$ and $\mathrm{Fe}$ in the red sand grains. The spectra 1 and 3 are similar to spectrum 2, showing the existence of a lead crystal. Spots 4 and 5 correspond to iron particles.

during cooling. From a more general point of view, it appears that road surfaces, which are in close contact with the vehicle emissions represent a main, long term sink for traffic-emitted pollutants (either from exhaust pipes or from abrasion), through crystallization, adsorption or trapping inside lipophilic phases, tar for instance (Nageotte and Day, 1998). As previously suggested by Sutherland (2003), this phenomenon may represent a major source of contamination.

\section{Conclusion}

The comparison of the two types of matrices (street dust and bark deposit) suggests that the coarse dense particles present in the dust may be at the origin of a secondary contamination of the finest dust fraction through slow transfer from sand to the fine atmosphere transported particles (clay) and to the highly bioavailable water soluble fraction during storms. If the accumulation of high amounts of anthropogenic elements in the coarse particles of road surfaces was demonstrated to be a general feature, it would amount to a valuable archive having high rate accumulation efficiency for metals such as $\mathrm{Pb}, \mathrm{Cu}$ and $\mathrm{Fe}$ over long periods of time.

\section{Acknowledgements}

We are grateful to Anne Laure Tissut for her fruitful suggestions about the English form and to Florence Sagnimorte for financial administration. We are grateful to the "Conseil Régional Rhône-Alpes" (INNOV'R program) for funding this project.

\section{References}

Amaral A.F.S., Arruda M., Cabral S., Rodrigues A.S. Essential and non-essential trace metals in scalp hair of men chronically exposed to volcanogenic metals in the Azores, Portugal. Environ. Int. 2008; 34:1104-1108.

Ayrault S., Roy-Barman M., Le Cloarec M.-F., Priadi C.,
Bonté P., Göpel C. Lead contamination of the Seine River, France: geochemical implications of a historical perspective. Chemosphere 2012, 97:902-910.

Bargagli R. Higher plant as biomonitors of airborn trace elements. In Trace Elements in Terrestrial Plants: an Ecophysiological Approach to Biomonitoring and Biorecovery. Ed. R. Bargagli. 1998, pp. 238-262. Springer-Verlag, Berlin, Heidelberg, New York.

Bellis D.J., Satake K., Nodal M., Nishimura N., McLeod C.W. Evaluation of the historical records of lead pollution in the annual growth rings and bark pockets of a 250-year-old Quercus crispula in Nikko, Japan. Sci. Total Environ. 2002, 295, 91-100.

Catinon M., Ayrault S., Daudin L., Sevin L., Asta J., Tissut M., Ravanel P., 2008. Atmospheric inorganic contaminants and their distribution inside stem tissues of Fraxinus excelsior L. Atmos. Environ. 2008, 42, 1223-1238.

Catinon M., Ayrault S., Clocchiatti R., Boudouma O., Asta J., Tissut M., Ravanel P., 2009. The anthropogenic atmospheric elements fraction: a new interpretation of elemental deposits on tree barks. Atmos. Environ. 43, 1124-1130.

Catinon M, Ayrault S, Spadini L, Boudouma O, Tissut M, Ravanel P. Tree bark suber-included particles: a long-term accumulation site for elements of atmospheric origin. Atmos. Environ. 2011, 45, 1102-1109.

Cirera L., Rodríguez M., Giménez J., Jiménez E., Saez M., Guillén J.-J., Medrano J., Martínez-Victoria M.-A., Ballester F., Moreno-Grau S., Navarro C. Effects of public health interventions on industrial emissions and ambient air in Cartagena, Spain. Environ. Sci. Pollut. Res. 2009. 16, 152-161.

Cizdziel J.V., and Hodge V.F. Attics as archives for house infiltrating pollutants: trace elements and pesticides in attic dust and soil from southern Nevada and Utah. Microchem. Journ. 2000.64, 85-92.

Costa D.L., Dreher K.L., Bioavailable transition metals 
in particulate matter mediate cardiopulmonary injury in healthy and compromised animal models. Environ. Health Perspect. 1997. 105, 1053-1060.

Davis J.J., Gulson B.L. Ceiling (attic) dust: A "museum" of contamination and potential hazard. Env. Res. 2005. 99, 177-194.

Harrison R. M., Smith D. J. T., Pio C. A., Castro L.M. Comparative receptor modelling study of airborne particulate pollutants in Birmingham (United Kingdom), Coimbra (Portugal) and Lahore (Pakistan). Atmos. Environ. 1997, 31, 3309-3321.

Iijima A., Sato K., Yano K., Kato M., Kozawa K., Furuta N. 2008. Emission factor for antimony in brake abrasion dusts as one of the major atmospheric antimony sources. Environ. Sci. Technol. 42, 2937-2942.

Kidd P., Barcelo J., Pilar Bernal M., Navari-Izzo F., Poschenrieder C., Shilev S., lemente R., Monterroso C. Trace element behaviour at the root-soil interface: implications in phytoremediation. Environ. Exp. Bot. 2009, 67, 243-259.

Kume A., Numata S., Watanabe K., Honoki H., Nakajima H., Ishida M. Influence of air pollution on the mountain forests along the Tateyama-Kurobe Alpine route. Ecol. Res. 2009. 24, 821-830.

Laidlaw M.A.S., Filippelli G.M. Resuspension of urban soils as a persistent source of lead poisoning in children: A review and new directions. Appl. Geochem. 2008. 23, 2021-2039.

Mondal N.C., Singh V.S., Puranik S.C., Singh V.P. Trace element concentration in groundwater of Pesarlanka Island, Krishna Delta, India. Environ. Monit. Assess. 2010. 163, 215-227.
Nageotte S.M., Day J.P. Lead concentrations and isotope ratios in street dust determined by electrothermal atomic absorption spectrometry and inductively coupled plasma mass spectrometry. Analyst 1998. 123, 59-62.

Sternbeck J., Sjödin Å., Andréasson K. Metal emissions from road traffic and the influence of resuspension-results from two tunnel studies. Atmos. Environ. 2002. 36, 4735-4744.

Sutherland R.A., Day J.P., Bussen J.O. Lead concentrations, isotope ratios and source apportionment in road deposited sediments, Honolulu, Oahu, Hawaii. Water, Air, and Soil Pollut. 2003. 142, 165-186.

Taylor S.R., McLennan S.M. 1985. The Continental Crust: Its Composition and Evolution. Blacwell Scientific Publications, Oxford, 312 p.

Thorpe A., Harrison R.M. Sources and properties of non-exhaust particulate matter from road traffic: A review. Sci. Total Environ. 2008, 400, 270-282.

Tye A.M., Hodgkinson E.S. and Rawlins, B.G. Microscopic and chemical studies of metal particulates in tree bark and attic dust: evidence for historical atmospheric smelter emissions, Humberside, UK. J. Environ. Monit. 2006, 8, 904-912.

Zereini F., Alt F., Messerschmidt J., Wiseman C., Feldmann I., Bohlen A.V., Muller J., Liebl K., Puttmann W. Concentration and distribution of heavy metals in urban airborne particulate matter in Frankfurt am Main, Germany. Environ. Sci. Technol. 2005, 39, 2983-2989. 